\title{
Mycosis Fungoides and Sezary Syndrome T4 TNM Finding v8
}

National Cancer Institute

\section{Source}

National Cancer Institute. Mycosis Fungoides and Sezary Syndrome T4 TNM Finding v8. NCl Thesaurus. Code C141338.

Confluence of erythema covering $80 \%$ or more of body surface area. (from AJCC 8th Ed.) 